\title{
Effects of perennial ('Russell') lupins on soil nitrogen and carbon in acid high-country soils
}

\author{
X. CHE ${ }^{1}$, J.L. MOIR ${ }^{1}$, A.D. BLACK ${ }^{1}$, H. SHENG ${ }^{2}$ and X. LI $^{2}$ \\ ${ }^{1}$ Soil Science Department, Lincoln University, PO Box 85084, Lincoln, New Zealand \\ ${ }^{2}$ College of Agriculture \& Animal Husbandry, Qinghai University, Xining, China \\ jim.moir@lincoln.ac.nz
}

\begin{abstract}
Many high-country soils in South Island have low soil $\mathrm{pH}$ and high exchangeable $\mathrm{Al}$ concentrations, limiting establishment and persistence of pasture and forage legumes. Perennial lupin (Lupinus polyphyllus) is able to grow in acidic soil $(\mathrm{pH}<5.6)$ with high levels of exchangeable $\mathrm{Al}\left(\mathrm{Al}>3 \mathrm{ppm}, 0.01 \mathrm{CaCl}_{2}\right)$ toxic to most other legumes. This study examined the effects of perennial lupin stands of varying ages on soil nitrogen $(\mathrm{N})$ and carbon $(\mathrm{C})$ concentrations $(0-15 \mathrm{~cm})$. Eight lupin sites, varying in age, and neighbouring long-term pasture sites were soil sampled and analysed for $\mathrm{N}$ and $\mathrm{C}$ concentrations. Sites planted with perennial lupin had significantly $(\mathrm{P}<0.001)$ higher total soil $\mathrm{N}(\%)$ and soil mineralisable $\mathrm{N}(\mathrm{kg} / \mathrm{ha})$ compared to adjacent pasture soils at the eights sites. Soil N status also declined with increasing soil depth in both lupin and pasture soils linked with plant residue accumulation in the topsoil. Soil $\mathrm{N}$ level generally increased with increasing lupin stand age $(\mathrm{P}<0.001)$, though the oldest $(30$ years $)$ site did not fit this trend. This study provides strong evidence that lupins substantially increase soil total and labile soil N. Results indicate that perennial lupins may be a suitable and important species to develop poor quality soils on South Island high-country farms.
\end{abstract}

Keywords: Lupinus polyphyllus, pasture, stand age, aluminium, acid soils

\section{Introduction}

The productivity of high-country pastures in South Island, New Zealand, is typified by a short, often soil moisture-limited growing season. Alternative pasture species have been suggested to improve dryland pasture production (McGowan et al. 2003; Brown et al. 2009), and moreover, the deep-rooting nature of lucerne (Medicago sativa) has highlighted the value of this species in dryland environments (Rechcigl et al. 1988; Su et al. 1996; Thomas 2003). However, lucerne is intolerant of acid soil conditions and associated aluminium (Al) toxicity (Rechcigl et al. 1988; Su et al. 1996).

Many South Island high-country soils have low soil $\mathrm{pH}$ and possibly high exchangeable $\mathrm{Al}$ concentrations (Moir \& Moot 2010, 2014). Soil acidity, coupled with toxic concentrations of exchangeable $\mathrm{Al}$, and low available phosphorus (P) and sulphur (S) further limits potential establishment and persistance of legumes (Haynes \& Williams, 1993; Moir et al. 2000). To neutralise increased soil acidity, lime must be applied, and where this is not economic soils may be too acidic for legumes, limiting productivity (Edmeades et al. 1983; Lanyon \& Griffith 1988). Often the cost of lime or its application is perceived as being uneconomic in extensive high-country regions. The relationship between pasture production and soil $\mathrm{pH}$ is well established on some high-country soils (Haynes \& Williams, 1993). Al concentration and in the same cases, the relative Al tolerance of some forage legumes have also been examined (Edmeades et al. 1991; Wheeler et al. 1992; Moir et al. 2016). However, studies of alternative legumes that are tolerant of low soil $\mathrm{pH}$ and high $\mathrm{Al}$ concentration in South Island highcountry soils are scarce (Moir et al. 2016).

Lupinus polyphyllus (common name: 'Russell' lupin), also known as perennial lupin, is a herbaceous perennial legume species which has the potential to improve soil N and biological N cycling (Scott 1989). Perennial lupin was grown in low fertility, acid soils, in the high-country near Mt John in Tekapo, in the studies by the late Dr David Scott (See page 269-276, this volume). It has been suggested that perennial lupin has the potential to replace traditionally used clover species in hill-country, where the soil fertility is marginal and the application of fertilisers and lime to improve this situation is uneconomic (Nordmeyer \& Davis 1977; Scott 1989; Wangdi et al. 1990), since it may have tolerance to high soil Al levels associated with acidic soils. Lupins are assumed to biologically fix atmospheric $\mathrm{N}$ into the soil/plant/animal ecosystem which benefits companion species including grasses. Lupin is dormant in the Mackenzie Basin during the winter, but grows well in the springtime when the temperatures are warmer (Taylor 2013).

In low P soils, lupin outyields clovers (Davis 1981a). This is because lupin forms mycorrhizal associations in the soil to increase the surface area for absorption of $\mathrm{P}$ and utilises $\mathrm{P}$ which is unavailable to most other plants (Davis 1981b). Perennial lupin has a large root system which in loose textured soils improves both the soil structure and reduces the rate of erosion, enhancing soil conservation (Rowland et al. 1986). 
Although recent research by Black et al. (2014) has indicated the productive performance of perennial lupin in low fertility acid high-country soils, the effects of lupin on soil $\mathrm{N}$ and $\mathrm{C}$ have not been studied. As such, the quantity of biological $\mathrm{N}$ inputs and effects of lupin on critical soil $\mathrm{N}$ and $\mathrm{C}$ biochemistry is unknown and undocumented in the scientific literature.

This research aims to quantify changes in soil $\mathrm{N}$ and $\mathrm{C}$ in low fertility, acid soils planted in perennial lupin, of varying ages, in the South Island to test the hypothesis (a) perennial lupin increases soil total and mineralisable $\mathrm{N}$ and total $\mathrm{C}$ in the plant rooting zone of low fertility acid high-country soils and (b) the extent of $\mathrm{N}$ accumulation in soils growing lupin is dependent on the age of the lupin stand. This paper is a preliminary account, and when the full data set has been collected, a final presentation of all results will follow.

\section{Materials and methods}

Eight separate dryland field sites growing sown perennial lupin (Lupinus polyphyllus) stands of varying ages were soil sampled across four South Island high-country farms (Sawdon, Glenmore, Omarama and Dasher Stations) and from one site at Lincoln University, Lincoln, Canterbury, in June 2017 (Table 1). As a comparative sample, neighbouring long-term pasture sites for each lupin stand were also collected. All sites were grazed by sheep, and pasture sites were ryegrass/cocksfoot/browntop-based, with a low clover component (subterranean-clover/annual adventive clovers/white clover).

With the exception of Omarama Station sites, each lupin and pasture site was core-sampled $(2.5 \mathrm{~cm}$ diameter) at two depths, 0-7.5 ('depth A') and 7.5-15 ('depth B') cm. The stoney soil conditions at Omarama site meant only a depth A sample could be taken. A sample consisted of 30 cores (bulked), and three replicate samples were taken at each site. Pasture soils were sampled randomly over large areas (e.g. 10 ha or greater) using $50 \mathrm{~m}$ long GPS transects, while lupin soils were often sampled from smaller experimental trial sites. For lupin sites, soil cores were taken $15 \mathrm{~cm}$ away from the central crown of the lupin plant to ensure that rhizosphere or "rhizosphere influenced" soil was being sampled, but not root nodules. At typical plant densities for these sites, $15 \mathrm{~cm}$ from the crown usually represented the mid-way point between plants.

All soil samples were analysed for total soil $\mathrm{N}$, total soil C (Leco combustion), mineral N, and mineralisable $\mathrm{N}$ measured by the method of Blakemore et al. (1972). All analyses were conducted on air-dry $2 \mathrm{~mm}$ sieved soil, except mineral and mineralisable $\mathrm{N}$ analyses, which were conducted on fresh homogenised fieldmoist soil. Bulk samples were analysed for soil $\mathrm{pH}$, Olsen P, and sulphate S. Soil $\mathrm{pH}$ was measured at a water: soil ratio of 2.5: 1 (Blakemore et al. 1972). The Olsen $\mathrm{P}$ was measured by using the method of Olsen et al. (1954). Extractable soil sulphate was measured by the method of Searle (1979). A modified method of Keeney \& Bremner (1966) was used to measure soil mineralisable N. In general, Olsen P was around 12$18 \mathrm{mg} / \mathrm{L}$ and sulphate $\mathrm{S}$ was $2-10 \mathrm{mg} / \mathrm{kg}$ at the sites. pH's were low (5.0-5.6) at most sites, except at Lincoln University which was $\mathrm{pH} 6.0$.

All data sets were analysed to test for treatment effects by conducting an analysis of variance (ANOVA) using GENSTAT 16 (Lawes Agricultural Trust, Rothamsted, $\mathrm{UK}$ ). These included total soil $\mathrm{N}$, total soil $\mathrm{C}$, soil mineralisable $\mathrm{N}$ and soil mineral $\mathrm{N}$.

\section{Results}

\section{Observed trends in lupin sites}

Total soil $\mathrm{N}$ concentrations (\%) showed large variation between sites $(\mathrm{P}<0.001)$ ranging from $0.21 \%$ at site 7 to $0.68 \%$ at site 2 (Table 2 ). Total Soil $\mathrm{N}$ values were also strongly different $(\mathrm{P}<0.001)$ between lupin and pasture

Table 1 Site code, location, soil order, fertiliser histories, plant history and climate information of eight separate lupin-based sites across four high-country farms and the Lincoln University Campus.

\begin{tabular}{|c|c|c|c|c|c|c|c|}
\hline $\begin{array}{l}\text { Site } \\
\text { code }\end{array}$ & Farm & Location & Soil order & $\begin{array}{l}\text { Fertiliser } \\
\text { history }\end{array}$ & Plant species & $\begin{array}{c}\text { Annual } \\
\text { rainfall }(\mathrm{mm})\end{array}$ & $\begin{array}{l}\text { Altitude } \\
\text { (m a.s.l.) }\end{array}$ \\
\hline 1 & Glenmore station & Tekapo & Brown & Low-med & Lupin/cocksfoot & 590 & 700 \\
\hline 2 & Glenmore original & Tekapo & Brown & Low-med & Lupin/native grass & 590 & 720 \\
\hline 3 & Glenmore Stn Dan & Tekapo & Brown & Med & Lupin & 590 & 650 \\
\hline 4 & Glenmore Stn Wild & Tekapo & Brown & Low & Lupin & 590 & 700 \\
\hline 5 & Sawdon station & Tekapo & Brown & Nil/Recent & $\begin{array}{l}\text { Lupin/cocksfoot/ } \\
\text { native grass }\end{array}$ & 600 & 700 \\
\hline 6 & Omarama station & Omarama & Recent & Nil & Lupin & 400 & 490 \\
\hline 7 & Dasher station & East Otago & Brown & Nil & Lupin & 1000 & 450 \\
\hline 8 & L.U. Campus & $\begin{array}{l}\text { Lincoln } \\
\text { University }\end{array}$ & $\begin{array}{l}\text { Templeton } \\
\text { silt loam }\end{array}$ & Low & Lupin/cocksfoot & 640 & 9 \\
\hline
\end{tabular}


soils. Soil total $\mathrm{N}$ was always higher at lupin than at pasture sites at the same soil depth (Figure 1). In terms of profile depth, depth A always had higher total $\mathrm{N}$ than depth B.

Further, significant effects were apparent for site by species $(\mathrm{P}<0.001)$, species by depth $(\mathrm{P}<0.001)$ and site by species by depth interactions $(\mathrm{P}<0.001)$.

Total soil $\mathrm{C}$ concentrations also differed $(\mathrm{P}<0.001)$ between sites and varied from $2.2 \%$ at site 7 to $8.5 \%$ at site 2. Total soil $\mathrm{C}$ in perennial lupin soils was higher than in neighbouring pasture soils $(\mathrm{P}<0.001$, Figure 1$)$. Total soil $\mathrm{C}$ in depth A was always higher than in depth $\mathrm{B}(\mathrm{P}<0.001)$. The highly significant differences were observed in site by species $(\mathrm{P}<0.001)$, species by depth $(\mathrm{P}<0.001)$ and site by species by depth interactions $(\mathrm{P}<0.001)$, while there a significant $(\mathrm{P}<0.05)$ site by depth interaction.

Total soil $\mathrm{N}$ and total soil $\mathrm{C}$ values in depth $\mathrm{A}$ increased with increasing lupin stand age at sites 1 , 2, 6 and 8 , but not at site 7 (Table 2). Total soil N and $\mathrm{C}$ showed intermediate values for sites 5 and site 4 (10 and 30 year old lupin stands, respectively). Compared with site 8 and site 6 , soil mineralisable $\mathrm{N}$ showed higher values in site 7 and site 3 with the same lupin age. Soil mineral $\mathrm{N}$ values in depth B changed irregularly with increasing lupin age. However, site 1, 2, 3 and 8 showed increasing soil mineralisable $\mathrm{N}$ as lupin stand age increased.

\section{Comparison of lupin and pasture soils}

For soil mineralisable N, the values differed strongly $(\mathrm{P}<0.001)$ between the eight sites, ranging from site $8(37.1 \mathrm{~kg} / \mathrm{ha})$ to site $2(213.2 \mathrm{~kg} / \mathrm{ha})$. A strong species (lupin or pasture) difference $\quad(\mathrm{P}<0.001)$ was also observed. The values for lupin soils were generally higher than for pasture for both soil profile depths at each site and depth A always had presented. higher values than depth $\mathrm{B}$. There were highly significant differences for site by species $(\mathrm{P}<0.001)$, species by depth $(\mathrm{P}<0.001)$ and site by species by depth interactions $(\mathrm{P}<0.001)$. At the same time, there was a significant difference $(\mathrm{P}<0.001)$ in soil mineralisable $\mathrm{N}$ affected by lupin stand age, where values were higher for older stands (Table 2). An interaction of soil depth and lupin stand age $(\mathrm{P}<0.001)$ was found for soil mineralisable $\mathrm{N}$. Soil mineral $\mathrm{N}$ was different $(\mathrm{P}<0.001)$ between the eight sites, with a range of $3.7-59.5 \mathrm{~kg} / \mathrm{ha}$. A strong difference $(\mathrm{P}<0.001)$ was found in soil mineral $\mathrm{N}$ between sites planted with perennial lupin compared with the sites in pasture, and the maximum value for lupins $(59.5 \mathrm{~kg} / \mathrm{ha})$ was double that of pasture soil $(24.5 \mathrm{~kg} / \mathrm{ha})$.

\section{Discussion}

Overall, there was a strong difference in total soil $\mathrm{N}$ concentrations between lupin and adjacent long-term

Table 2 Mean total soil $\mathrm{C}$ and $\mathrm{N}$ and mineral and mineralisable $\mathrm{N}$ of lupin soils with 2 depths for different lupin stand ages across eight sites. Data for pasture sites not

\begin{tabular}{|c|c|c|c|c|c|c|}
\hline Site & $\begin{array}{l}\text { Site Age } \\
\text { (Years) }\end{array}$ & $\begin{array}{l}\text { Sample } \\
\text { depth }\end{array}$ & $\begin{array}{c}\text { Total soil } \\
\text { N (\%) }\end{array}$ & $\begin{array}{l}\text { Total soil } \\
\text { C (\%) }\end{array}$ & $\begin{array}{c}\text { Mineral } \\
\text { N (kg/ha) }\end{array}$ & $\begin{array}{c}\text { Mineralisable } \\
\text { N (kg/ha) }\end{array}$ \\
\hline \multirow[t]{2}{*}{1} & 5 & $A$ & 0.63 & 7.5 & 11 & 172 \\
\hline & & B & 0.37 & 4.2 & 4 & 43 \\
\hline \multirow[t]{2}{*}{2} & 7 & $A$ & 0.68 & 8.5 & 18 & 214 \\
\hline & & B & 0.42 & 4.6 & 5 & 56 \\
\hline \multirow[t]{2}{*}{3} & 3 & $A$ & 0.44 & 5.3 & 25 & 87 \\
\hline & & B & 0.31 & 3.3 & 10 & 40 \\
\hline \multirow[t]{2}{*}{4} & 30 & $A$ & 0.46 & 5.5 & 18 & 103 \\
\hline & & B & 0.34 & 3.7 & 11 & 48 \\
\hline \multirow[t]{2}{*}{5} & 10 & $A$ & 0.32 & 3.4 & 22 & 91 \\
\hline & & B & 0.26 & 2.7 & 15 & 55 \\
\hline 6 & 3 & $A$ & 0.26 & 2.8 & 11 & 51 \\
\hline \multirow[t]{2}{*}{7} & 2 & $A$ & 0.51 & 6.4 & 60 & 166 \\
\hline & & B & 0.39 & 4.8 & 21 & 98 \\
\hline \multirow[t]{8}{*}{8} & 2 & $A$ & 0.22 & 2.4 & 10 & 37 \\
\hline & & B & 0.21 & 2.3 & 9 & 30 \\
\hline & Mean & $A$ & 0.44 & 5.2 & 22 & 115 \\
\hline & & B & 0.33 & 3.7 & 11 & 53 \\
\hline & Depth & SEM & 0.020 & 0.27 & 2.6 & 7.9 \\
\hline & & $\mathrm{LSD}_{5 \%}$ & 0.041 & 0.55 & 5.3 & 15.8 \\
\hline & Site Age & SEM & 0.036 & 0.48 & 4.6 & 13.8 \\
\hline & & $\mathrm{LSD}_{5 \%}$ & 0.082 & 0.97 & 9.3 & 27.8 \\
\hline \multirow[t]{3}{*}{$\mathrm{P}$} & Depth & & 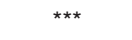 & $* \star *$ & $* \star *$ & $\star \star \star *$ \\
\hline & Site Age & & $\star \star \star *$ & $* \star *$ & $\star *$ & $\star \star \star *$ \\
\hline & Depth $x$ Site & Age & ** & ** & NS & $\star \star \star$ \\
\hline
\end{tabular}

${ }^{\star \star \star *}$ significant at $\mathrm{P}<0.001,{ }^{\star \star}$ significant at $\mathrm{P}<0.01, \mathrm{NS}=$ not significant + : Soil depth 'A' = 0-7.5 cm, Soil depth 'B' = 7.5-15 cm 

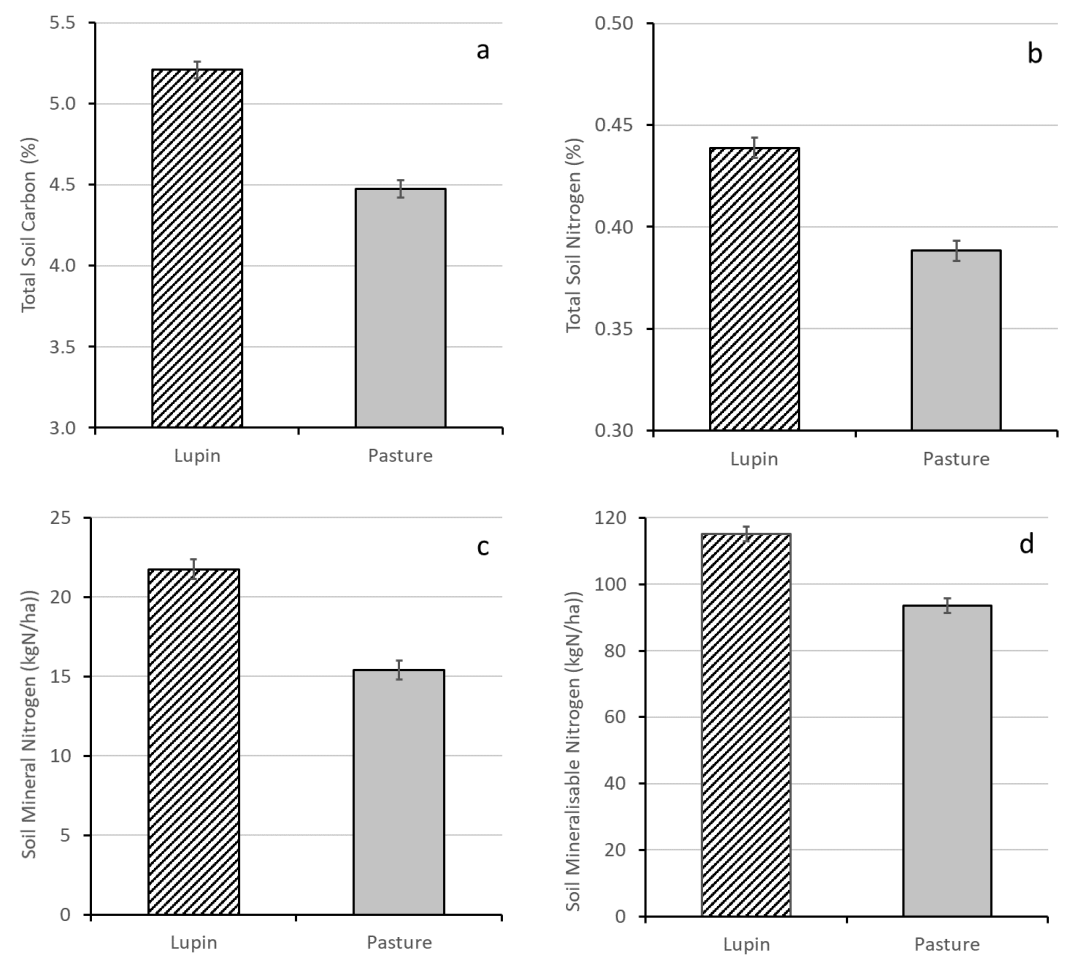

Figure 1 Mean soil: a) total soil nitrogen concentrations (\%), b) total soil carbon, c) mineral nitrogen and d) mineralisable nitrogen (0-7.5 cm soil horizon) of lupin and long-term pasture sites in South Canterbury high-country and at Lincoln University. $n=8$, error bars are \pm 1 SEM

pasture soils under dryland (Figure 1). The data showed that growing perennial lupins resulted, on average, in higher levels of total soil $\mathrm{N}$, soil mineral $\mathrm{N}$ and mineralisable $\mathrm{N}$ than those growing pasture. This is a new and important finding.

Generally, lupin soils had higher soil $\mathrm{N}$ and $\mathrm{C}$ values than pasture sites, such as at sites 1 and site 2 . Waring \& Gibson (1994) and Hossain et al. (1996) showed similar changes of plant available soil $\mathrm{N}$ after introducing legumes into the pasture. In that study, higher soil mineralisable $\mathrm{N}$ occurred in legume-based soils than original pasture or cropping soils. Exceptions to this overall trend were sites 7 and 8 . Site 8 showed higher soil mineralisable $\mathrm{N}$ in pasture soils at both depths and site 7 showed higher pasture soil mineralisable $\mathrm{N}$ in the depth A. Site 8 also showed a different result compared to the other seven sites in terms of total soil $\mathrm{N}$ and $\mathrm{C}$ which can be explained by the conditions at the site. Site 8 was at Lincoln University, located in Christchurch with lower altitude, higher annual average temperature and rainfall and lower soil acidity $(\mathrm{pH}$ 6.0) than the other high-country sites. This likely resulted in less chilling stress, less drought stress and less $\mathrm{Al}$ toxicity for both lupin and pasture. The lupin stand at Lincoln University was also a mixed sward with low abundance of lupin and therefore a high abundance of grasses with greater ability to utilise soil mineral $\mathrm{N}$. The low lupin plant density at this site could have resulted in lower total soil $\mathrm{N}$ and soil $\mathrm{C}$ accumulation compared to the other sites and with higher total soil $\mathrm{N}$ and $\mathrm{C}$ in pasture soils.

Depth A always had higher $\mathrm{N}$ values in all the lupin sites, although the differences between two depths varied between sites. This is consistent with the trend of soil $\mathrm{N}$ changes by soil depths under pasture, as shown by Hossain et al. (1996), using the same incubation method. This study found the same trend for soil mineralisable $\mathrm{N}$ with depth planted with perennial lupin.

Data indicated that total soil $\mathrm{N}$ and $\mathrm{C}$ both had strong $(\mathrm{P}<0.001)$ siterelated differences. Site 3 had the lowest values for the youngest lupin and site 2 had highest values for 7 year old lupin stands. The same trend also demonstrated for mean soil mineralisable $\mathrm{N}$ that was higher where the lupin stand was older. The lupin soils had higher total soil N (\%) than those under pasture at both depths, supporting the findings of Watson (1963) (subterranean clover) and Vallis (1972) (clover/grass mixes). These results provide some evidence of soil $\mathrm{N}$ accumulation with increasing age of the lupin stand. However, more research incorporating more sites is required to confirm any temporal effects.

Soil total C (\%) data showed highly significant $(\mathrm{P}<0.001)$ differences between the forage types. Perennial lupin sites generally had higher total soil C (\%) than the pasture sites, which is a new finding. This may have resulted from decreasing soil organic $\mathrm{C}$ in long-term pasture land (Schipper et al. 2007) and increased soil $\mathrm{C}$ content from growing a legume based sward (Conant et al. 2001). It has been reported that introducing legumes into pasture system often resulted in increased DM production and biomass production below-ground (Robinson \& Jacques 1958; Crawford et al. 1996; Conant et al. 2001) and soil C. Post et al. (1982) reported that the amount of soil C is strongly correlated with annual rainfall. Similarly, Adams (1980) reported that total soil organic $\mathrm{C}$ content increased with 
precipitation and decreased with temperature. Total soil $\mathrm{C}$ differences between the sites in this study were likely influenced by interactions of climate, soil conditions and plant species, though further research is required to confirm this.

It is important to note the limitation of the data presented as only eight sites were studied. As such, further research is required to confirm the findings reported here. Larger numbers of sites should be studied in future, to improve knowledge of the temporal differences in soil $\mathrm{N}$ and $\mathrm{C}$ status between lupin growing soils and those supporting long-term pasture, and the soil $\mathrm{N}$ change as affected by lupin stand age.

\section{ACKNOWLEDGEMENTS}

Qian Liang and Vicky Zhang, Lincoln University AGLS Analytical services for nitrogen analyses. Amy Whitley and Daniel Hendrie for advice and field site information. Thanks to all the farmers who allowed us to sample their farms. Last, but not least, the late Dr David Scott, for his advice, support and enthusiasm. This research was funded by the MBIE NZ/China strategic fund, MBIE contract LINX1404 and MOST contract 2015DFG31870.

\section{REFERENCES}

Adams, F. 1980. Interactions of phosphorus with other elements in soils and in plants. The role of phosphorus in agriculture. pp. 655-680.

Arrouays, D.; Pelissier, P. 1994. Modeling carbon storage profiles in temperate forest humic loamy soils of France. Soil Science 157: 185-192.

Black, A.D.; Loxton, G.; Ryan-Salter, T.P.; Moot, D.J. 2014. Sheep performance on perennial lupins over three years at Sawdon Station, Lake Tekapo. Proceedings of the New Zealand Grassland Association 76: 35-40.

Blakemore, L.; Searle, P.; Daly, B. 1972. Methods for chemical analyses of soils. New Zealand Soil Bureau Science Report 10 A. New Zealand Soil Bureau, Wellington.

Brown, H.E.; Moot, D.J.; Fletcher, A.L.; Jamieson, P.D. 2009. A framework for quantifying water extraction and water stress responses of perennial lucerne. Crop and Pasture Science 60: 785-794.

Carlsson, G.; Huss-Danell, K. 2003. Nitrogen fixation in perennial forage legumes in the field. Plant and Soil 253: 353-372.

Cassman, K.; Munns, D. 1980. Nitrogen mineralization as affected by soil moisture, temperature, and depth. Soil Science Society of America Journal 44: 12331237.

Crawford, M.; Grace, P.; Bellotti, W.; Oades, J. 1996. Below-ground inputs of carbon by crops and pastures
Proceedings of the 8th Australian Agronomy Conference Queensland, Australia. pp. 172-175.

Davis, M. 1981a. Growth and nutrition of legumes on a high country yellow-brown earth subsoil: II. A comparison of tropical and temperate species. New Zealand Journal of Agricultural Research 24: 333337.

Davis, M. 1991. The comparative phosphorus requirements of some temperate perennial legumes. Plant and Soil 133: 17-30.

Dividson, E.; Stark, J.M. Firestone, M. 1990. Microbial production and consumpution of nitrate in an annual grassland. Ecology 71: 1968-1975.

Edmeades, D.; Blamey, F.; Asher, C.; Edwards, D. 1991. Effects of $\mathrm{pH}$ and aluminium on the growth of temperate pasture species. I. Temperate grasses and legumes supplied with inorganic nitrogen. Australian Journal of Agricultural Research 42: 559-569.

Edmeades, D.; Smart, C.; Wheeler, D. 1983. Aluminium toxicity in New Zealand soils: preliminary results on the development of diagnostic criteria. New Zealand Journal of Agricultural Research 26: 493-501.

Haynes, R.; Williams, P. 1993. Nutrient cycling and soil fertility in the grazed pasture ecosystem. Advances in Agronomy 49: 119-199.

Hoglund, J.; Crush, J.; Brock, J.; Ball, R.; Carran, R. 1979. XII. General discussion. New Zealand Journal of Experimental Agriculture 7: 45-51.

Hossain, S.; Dalal, R.; Waring, S.; Strong, W.; Weston, E. 1996. Comparison of legume-based cropping systems at Warra, Queensland. 1. Soil nitrogen and organic carbon accretion and potentially mineralisable nitrogen. Soil Research 34: 273-287.

Jackman, R. 1964. Accumulation of organic matter in some New Zealand soils under permanent pasture: I. Patterns of change of organic carbon, nitrogen, sulphur, and phosphorus. New Zealand Journal of Agricultural Research 7: 445-471.

Jarvis, S.C.; Stockdale, E.A.; Shepherd, M.A.; Powlson, D.S. 1996. Nitrogen mineralization in temperate agricultural soils: processes and measurement. Advances in Agronomy 57: 187-235.

Jobbágy, E.G.; Jackson, R.B. 2001. The distribution of soil nutrients with depth: global patterns and the imprint of plants. Biogeochemistry 53: 51-77.

McGowan, A.; Sheath, G.; Webby, R. 2003. Lucerne for high quality summer feed in North Island hill country. Legumes for dryland pastures. Grassland Research and Practice Series 11: 169-174.

Moir, J.L.; Hedley, M.; Mackay, A.; Tillman, R. 1997. The effect of fertiliser history on nutrient accumulation and plant-available nutrient supply in legume-based pasture soils. Proceedings of the XVII International Grassland Congress. Session 10: 6869. 
Moir, J.L.; Jordan, P.; Moot, D.J.; Lucas, R. 2016. Phosphorus response and optimum $\mathrm{pH}$ ranges of twelve pasture legumes grown in an acid upland New Zealand soil under glasshouse conditions. Journal of Soil Science and Plant Nutrition 16: 438-460.

Moir, J.L.; Scotter, D.R.; Hedley, M.J.; Mackay, A. 2000. A climate-driven, soil fertility dependent, pasture production model. New Zealand Journal of Agricultural Research 43: 491-500.

Moir, J.L.; Moot, D.J. 2010. The effects of soil pH and liming on lucerne grown in South Island high country. Proceedings of the New Zealand Grassland Association 72: 191-196.

Moir, J.L.; Moot, D.J. 2014. Medium-term soil pH and exchangeable aluminium response to liming at three high country locations. Proceedings of the New Zealand Grassland Association 76: 41-46.

Nordmeyer, A.; Davis, M. 1977. Legumes in high country development. Proceedings of the New. Zealand Grassland Association 39: 119-125.

Olsen, S.; Cole, C.V.; Watanabe, F.S.; Dean, L.A. 1954. Estimation of available phosphorus in soils by extraction with sodium bicarbonate. United States Department of Agriculture; Washington.

Post, W.M.; Emanuel, W.R.; Zinke, P.J.; Stangenberger, A.G. 1982. Soil carbon pools and world life zones. Nature 298: (5870) 156.

Rechcigl, J.E.; Reneau Jr, R.; Zelazny, L.W. 1988. Soil solution $\mathrm{Al}$ as a measure of $\mathrm{Al}$ toxicity to alfalfa in acid soils. Communications in Soil Science and Plant Analysis 19: 989-1001.

Rowland, I.; Mason, M.; Hamblin, J. 1986. Effects of lupins on soil fertility. Proceedings of the fourth International Lupin Conference: August 15-22, 1986, Geraldton, Western Australia. Western Australian Department of Agriculture.

Ryan-Salter, T.; Black, A.; Lucas, D.; Moot, D. 2013. Agronomic potential of Russell lupin (Lupinus polyphyllus L.) as a legume for high country grazing systems. Agricultural Group Lincoln University. pp. $1-36$.
Schipper, L.; Baisden, W.; Parfitt, R.; Ross, C.; Claydon, J.; Arnold, G. 2007. Large losses of soil $\mathrm{C}$ and $\mathrm{N}$ from soil profiles under pasture in New Zealand during the past 20 years. Global Change Biology 13: 1138-1144.

Scott, D. 1989. Perennial or Russell lupin: a potential high country pasture legume. Proceedings of the New Zealand Grassland Association 50: 203-206.

Searle, P. 1979. Measurement of adsorbed sulphate in soils-effects of varying soil: extractant ratios and methods of measurement. New Zealand Journal of Agricultural Research 22: 287-290.

Silver, W.; Hardy, W. 1976. Newer developments in biological dinitrogen fixation of possible relevance to forage production. Biological $N$ fixation in foragelivestock systems (biologicalnfixa): 1-34.

Su, Y.; Evans, A.; Brunnschweiler, A. 1996. Micromachined silicon cantilever paddles with piezoresistive readout for flow sensing. Journal of Micromechanics and Microengineering 6: 69.

Thomas, R. 2003. Comparative growth forms of dryland forage legumes. Grasslands Research and Practice Series 11: 19-26.

Vallis, I. 1972. Soil nitrogen changes under continuously grazed legume-grass pastures in subtropical coastal Queensland. Australian Journal of Experimental Agriculture 12: 495-501.

Wangdi, K.; McKenzie, B.; Hill, G. 1990. Field establishment of Russell lupin. Proceedings of the Agronomy Society of New Zealand 20: 29-36.

Waring, S.; Gibson, T. 1994. The soil fertility effects of leguminous ley pastures in north-east Thailand. II. Effects on soil physical and chemical parameters. Field Crops Research 39: 129-137.

Watson, E. 1963. The influence of subterranean clover pastures on soil fertility. I. Short-term effects. Australian Journal of Agricultural Research 14: 796-807.

Wheeler, D.; Edmeades, D.; Christie, R.; Gardner, R. 1992. Effect of aluminium on the growth of 34 plant species: a summary of results obtained in low ionic strength solution culture. Plant and Soil 146: 61-66. 